\title{
The flower flies and the unknown diversity of Drosophilidae (Diptera): a biodiversity inventory in the Brazilian fauna
}

\author{
Hermes José Schmitz ${ }^{1}$ \&era Lúcia da Silva Valente ${ }^{1,2}$ \\ 1 Universidade Federal da Integração Latino-Americana (UNILA), Instituto Latino-Americano de Ciências da Vida e da Natureza (ILACVN). \\ Foz do Iguaçu, PR, Brasil. ORCID: http://orcid.org/0000-0003-4487-1898. E-mail: hj.schmitz@gmail.com \\ 2 Universidade Federal do Rio Grande do Sul (UFRGS), Instituto de Biociências (IBIO), Departamento de Zoologia, \\ Programa de Pós-Graduação em Genética e Biologia Molecular (PPGBM). Porto Alegre, RS, Brasil. \\ ORCID: http://orcid.org/0000-0001-8661-6284. E-mail: vera.gaiesky@ufrgs.br
}

\begin{abstract}
Diptera is a megadiverse order, reaching its peak of diversity in Neotropics, although our knowledge of dipteran fauna from this region is grossly lacking. This applies even to the most studied families, such as Drosophilidae. Despite its prominence, most aspects of the biology of these insects are still poorly understood, especially those linked to natural communities. Field studies on drosophilids are highly biased towards fruit-breeding species. Flower-breeding drosophilids, however, are worldwide distributed, especially in tropical regions, although being mostly neglected. The present paper shows the results of a biodiversity inventory of flower-breeding drosophilids carried out in several localities in Brazil, based on samples of 125 plant species, from 47 families. Drosophilids were found in flowers of 56 plant species, from 18 families. The fauna discovered turned out to be mostly unknown, comprising 28 species, with 12 of them (> 40\%) still undescribed. Not taking into account opportunistic species, two-thirds of the flower-exclusive diversity was undescribed. The Drosophila bromeliae species group was the most representative taxon, with eight species (six undescribed), including four polyphagous and four Solanum-specialized species. This specialization on Solanum is reported for the first time for Drosophilidae. Other taxa of restricted flower-breeding drosophilids were the Drosophila lutzii species group and two species of the genus Zygothrica Wiedemann. Some specimens of the genera Cladochaeta Coquillett, Rhinoleucophenga Hendel and Scaptomyza Hardy were found, but their relations to flowers are unclear. Additionally, ten species of broad niche were found using flowers opportunistically. Localities and host plants were recorded for all species collected.
\end{abstract}

Key-Words. Drosophila; Flower-breeding drosophilids; Flower visitors; Host plants; Niche.

\section{INTRODUCTION}

Dealing with the huge diversity of living forms is one of the major challenges for biological sciences. Estimates range from three to 100 million species, the most plausible ones being in the 5-10 range with a great portion of this biodiversity, including insects, experiencing high levels of human-caused threats (May, 2010; Sánchez-Bayo \& Wyckhuys, 2019). Invertebrate and, especially, insect diversity accounts for a great proportion of the total biodiversity. Almost one million species of insects are formally described worldwide; Brazil, with a huge territory and an outstanding environmental heterogeneity, is a key country in this context, housing the highest insect diversity in the world. Estimates indicate that Brazilian fauna harbors 500 thousand to one million insect species, around $10 \%$ of the insect diversity on Earth (Rafael et al., 2009).
Diptera is one of the megadiverse orders, comprising alone about $10 \%$ of the world's biodiversity. The Neotropics appear to be the most diverse region regarding these insects, although our knowledge of Neotropical dipteran fauna remains grossly deficient (Brown, 2005). This is true even for the most studied families, such as Drosophilidae. For more than one century, species of Drosophila Meigen are largely used as model organisms for a variety of studies, especially in genetic and evolutionary research (Powell, 1997). This undoubtedly has brought exceptional attention to this group of organisms, stimulating early studies on taxonomy and natural history of the family (Sturtevant, 1916, 1921; Duda, 1925, 1927). In spite of this prominence, most aspects of the biology of these insects are poorly understood, especially those linked to natural communities.

The diversity of the family is also barely assessed. This family is one of the larger in Diptera, 
possessing more than 4,000 described species (Yassin, 2013), with a great number pending formal description. The Brazilian fauna of drosophilids has been researched for a long time (Dobzhansky \& Pavan, 1943, 1950; Pavan $\&$ Cunha, 1947) and more than three hundred species are recorded (Tidon et al., 2019). Therefore, records of drosophilids in Brazilian territory are strikingly concentrated in some regions, and inventories for most regions are still lacking (Chaves \& Tidon, 2008; Gottschalk et al., 2008). Furthermore, samples are greatly biased to fruit-breeders and species attracted to banana-baited traps.

Brncic (1983) listed 140 worldwide species of drosophilids associated with flowers in some manner. This number includes from very generalist species, which use flowers opportunistically, to specialized species, which depend on the flowers in all stages of the life cycle. These latter species are rarely detected in the traditional samples taken with fruit baits. In Neotropics, the best-studied flower-specialized species belong to the Drosophila flavopilosa species group (Brncic, 1962a, 1966, 1978; Santos \& Vilela, 2005; Robe et al., 2013), associated to flowers of the genus Cestrum (Solanaceae). Other notable anthophilic Drosophila taxa in Neotropical region are the $D$. bromeliae and $D$. lutzii species groups, both widespread in the Neotropics and associated to flowers of several botanical families (Chassagnard \& Tsacas, 1992; Silva \& Martins, 2004; Grimaldi, 2016; Vilela \& Prieto, 2018); the D. onychophora and D. xanthopallescens species groups, reported respectively to the northern Andes and Central America (Pipkin, 1964; Hunter, 1979), and some species of uncertain affinities associated to Araceae inflorescences (Tsacas \& Chassagnard, 1992; Vaz et al., 2014, 2018; Llangarí \& Rafael, 2017). Reports from other genera are also known, especially for Zygothrica Wiedemann (Grimaldi, 1987; Endara et al., 2010; Fonseca et al., 2017) and the poorly known Laccodrosophila Duda and Zapriothrica Wheeler (Heed et al., 1960).

Anthophilic drosophilids, therefore, are present worldwide, especially in tropical regions. Other noteworthy examples are the Scaptodrosophila aterrima species group in Africa (Tsacas et al., 1988), the subgenus Exalloscaptomyza Hardy of Scaptomyza Hardy, in Hawaii (Montague \& Kaneshiro, 1982; Starmer \& Bowles, 1994), Scaptodrosophila hibisci (Bock) and S. aclinata (McEvey \& Barker), in Australia (Cook et al., 1977; McEvey \& Barker, 2001), the Drosophila elegans species subgroup (melanogaster group) (Sultana et al., 1999), the genus Colocasiomyia de Meijere (Carson \& Okada, 1980; Sultana et al., 2006; Fartyal et al., 2013) and the genus Arengomyia Yafuso \& Toda (Yafuso et al., 2008), in Asia.

In addition to being normally neglected in diversity inventories, the nature of the interaction between drosophilids and flowers is poorly known in most cases, since flies may show different levels of dependence to flowers in all or just part of their life-cycles. In an attempt to both decrease the inventory gap and better comprehend such interactions, in the present paper we deal exclusively with flower-breeding species, that is, those that use flowers as oviposition sites. Thus, we report a diversity inventory of the Brazilian flower-breeding drosophilid fauna, based on an ample but not exhaustive sampling effort on a variety of plants, providing information on new host plants and localities, and the discovery of a highly unknown diversity, comprised mainly of undescribed species, with broader implications on the knowledge of Drosophilidae diversity in Neotropics.

\section{MATERIAL AND METHODS}

The present paper comprises samples taken opportunistically in several localities throughout the Brazilian territory (Fig. 1) between the years of 2006 and 2010. Most of the collections were carried out in the states of Rio Grande do Sul and Santa Catarina, the two southernmost Brazilian states. Additional samples were taken from the states of Paraná, São Paulo, Minas Gerais, Bahia, Pernambuco, and Pará. Coordinates were taken with GPS and are shown in Results. Most samples were taken in urban or peri-urban areas such as gardens, backyards, university campi, roadsides, and wastelands, although some were taken from natural forested areas, forest remnants or a natural restinga. The main environment of each locality is also indicated in the Results.

Flowers of 125 species of plants, from 47 families, were collected. They were detached during anthesis directly from the plants or collected as recently fallen flowers in the ground. They were put in plastic bags and taken to the laboratory, where they were transferred to vials with vermiculite, closed with foam stoppers and kept at $25^{\circ} \mathrm{C}$, being inspected for the emergence of drosophilid imagoes. In this case, the specimens were aspirated, aged for a few days in standard culture medium and identified by external morphology and terminalia, consulting specialized literature (Val, 1982; Vilela, 1984,

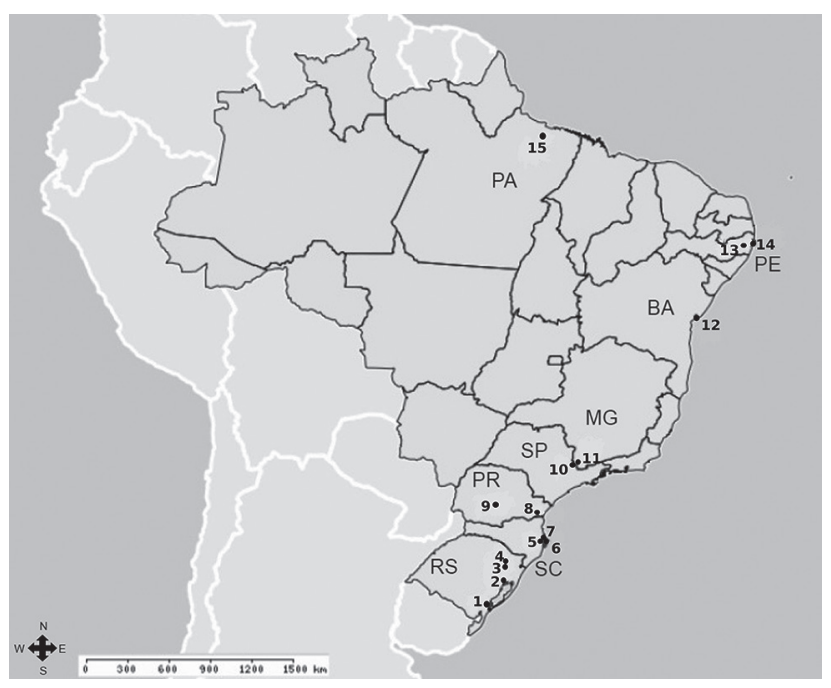

Figure 1. Map of Brazil showing the states and municipalities where new samples for this study were taken: RS = Rio Grande do Sul: (1) Pelotas, (2) Porto Alegre, (3) Caxias do Sul, (4) Flores da Cunha; SC = Santa Catarina: (5) Antônio Carlos, (6) Florianópolis, (7) Governador Celso Ramos; PR = Paraná: (8) São José dos Pinhais, (9) Guarapuava; SP = São Paulo: (10) Águas de Lindóia; $M G=$ Minas Gerais: (11) Monte Sião; BA = Bahia: (12) Itaparica; PE = Pernambuco: (13) Vitória de Santo Antão, (14) Recife; PA = Pará: (15) Belém. 
1986; Grimaldi, 1987, 2016; and others). The number of specimens collected was counted and given in the Results for each species, except for the Drosophila bromeliae and lutzii species groups. Since both of these groups have cryptic species that may occur concomitantly in the same hosts and females could not be readily discriminated, the total number of specimens of each cryptic species is not known (the total number of specimens was $>900$ for bromeliae and > 300 for lutzii species group). For analysis of terminalia, postabdomens were prepared following Bächli et al. (2004) and stored in microvials with glycerol. Ordinary specimens were kept in microtubes with ethanol $70 \%$ or pinned (double-mounted), associated with their respective terminalia in glycerol, in the Entomological Collection of Universidade Federal da Integração Latino-Americana (UNILA), Foz do Iguaçu, Brasil. As the specimens of $R$. joaquina were used to describe the new species, they were pinned and deposited in Entomological Collection of Fundação Oswaldo Cruz (CEIOC), Rio de Janeiro, Brazil. Vouchers of its host plant, Dyckia encholirioides, were deposited in Herbário ICN of Universidade Federal do Rio Grande do Sul (UFRGS), Porto Alegre, Brazil. Since many species found are probably undescribed and are currently being the object of further studies, any other specimen used to describe a new species will be deposited later, after taxonomic study, in CEIOC or other institution.

Plant species were identified after Souza \& Lorenzi (2005), references therein and other specialized literature. Eventually, some plants were identified by specialists (see Acknowledgments). Plants scientific names follow APG IV (2016) as in Plants of the World Online website (http://www.plantsoftheworldonline.org) or Flora do Brasil 2020 (http://www.floradobrasil.jbrj.gov.br).

\section{RESULTS}

\section{Fauna and flora}

From the 125 species of plants sampled, 56 turned out to host flower-breeding drosophilids, across 18 botanical families. Plant species with no emergence of drosophilids from our collections are listed in Appendix S1 in Supplementary Material.

In total, 28 species of drosophilids were found. The species found were loosely divided and presented below into three categories: (1) "restricted" (Table 1); (2) "uncertain biology" (Table 2); and (3) "opportunists" (Table 3). This approach tries to follow Brncic (1983) distinction between species for which "flowers seems to be preferred although not exclusive substrate" or "almost the exclusive site" (called here "restricted") and species that "utilize many other substrates for feeding and breeding, and flowers merely represent a secondary resource" (called here "opportunists"). To discriminate taxa between these two categories, Brncic (1983) was consulted, as well as studies on Brazilian frugivore or banana-baited traps assemblages (e.g., De Toni et al., 2001, 2007; Silva et al., 2005; Tidon, 2006; Gottschalk et al., 2007; Garcia et al.,
2012). The category "uncertain biology" comprises taxa that could not be assigned to any of these previous categories (see Discussion for more details).

\section{Localities}

The localities where which species was found are listed below. They are given from North to South, in the following format: State: Municipality, Locality (latitude; Iongitude; altitude, when available), type of environment.

\section{(1) "Restricted" flower-breeding species}

\section{Drosophila bromeliae species group}

Drosophila bromeliae Sturtevant. Pará: Belém, Reserva do Mocambo $\left(01^{\circ} 26^{\prime} 34.35^{\prime \prime} \mathrm{S} ; 48^{\circ} 24^{\prime} 35.59^{\prime \prime} \mathrm{W} ; 40 \mathrm{~m}\right)$, natural Amazon forest; Pernambuco: Recife, UFPE campus (08 $03^{\prime} 14^{\prime \prime}$; ; $\left.34^{\circ} 57^{\prime} 00^{\prime \prime} \mathrm{W}\right)$, urban area; Recife, UFRPE campus ( $\left.08^{\circ} 00^{\prime} 45^{\prime \prime} \mathrm{S} ; 34^{\circ} 56^{\prime} 57^{\prime \prime} \mathrm{W}\right)$, urban area; Vitória de Santo Antão, IFPE/Campus Vitória (0806'04.1"S; 35¹7'41.3"W; $152 \mathrm{~m}$ ), urban area; Mato Grosso: Tangará da Serra, "Park in town center" $\left(14^{\circ} 04^{\prime} 38^{\prime \prime} \mathrm{S} ; 57^{\circ} 03^{\prime} 45^{\prime \prime} \mathrm{W}\right)$ (specimens collected ["emerged from flowers from Convolvulaceae"] and cited as Drosophila sp.1 by Blauth \& Gottschalk, 2007 and reviewed by HJS). First records for Brazil (see Discussion).

Drosophila bromelioides Pavan \& Cunha. São Paulo: Águas de Lindóia, Morro do Cruzeiro (22²8'43"S; 46 37'34"W), peri-urban area; Paraná: Guarapuava, Parque do Lago (25²4'9.099"S; 51²8'30.82"W), urban area; Santa Catarina: Governador Celso Ramos, Anhatomirim Island (27 $25^{\prime} 38.09^{\prime \prime} \mathrm{S}$; $\left.48^{\circ} 33^{\prime} 53.89^{\prime \prime} \mathrm{W}\right)$, border of natural Atlantic forest; Florianópolis, Ratones Grande Island $\left(27^{\circ} 28^{\prime} 20.20^{\prime \prime}\right.$ S; $\left.48^{\circ} 33^{\prime} 43.00^{\prime \prime} \mathrm{W}\right)$, border of natural Atlantic forest; Antônio Carlos, Centro (2731'03.373"S; $\left.48^{\circ} 46^{\prime} 18.23^{\prime \prime} \mathrm{W}\right)$, urban area; Florianópolis, Ponta do Coral

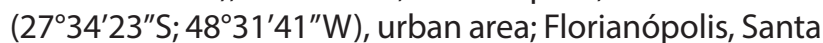
Mônica (273' $\left.34^{\prime \prime} ; 48^{\circ} 30^{\prime} 53^{\prime \prime} \mathrm{W}\right)$, urban area; Florianópolis, Morro da Lagoa da Conceição (27³5'40.9"S; 48²8'41.6"), natural Atlantic forest; Florianópolis, UFSC campus (2736'08.127"S;48³1'30.39"W), urbanarea; Florianópolis, Joaquina $\left(27^{\circ} 36^{\prime} 43.9^{\prime \prime} \mathrm{S} ; 48^{\circ} 26^{\prime} 36.3^{\prime \prime} \mathrm{W}\right)$, natural restinga/ sandy beach; Rio Grande do Sul: Caxias do Sul, Grupo de Escoteiros Saint Hilaire $\left(29^{\circ} 09^{\prime} 38.2^{\prime \prime} S\right.$; $51^{\circ} 08^{\prime} 31.7^{\prime \prime}$; $706 \mathrm{~m})$, urban area; Caxias do Sul, Marcopolo/BR-116 road (29¹1'06.4"S; 51¹0'23.8"W; $695 \mathrm{~m})$, urban area; Porto Alegre, Parque Farroupilha $\left(30^{\circ} 02^{\prime} 13.0^{\prime \prime} \mathrm{S}\right.$; $\left.51^{\circ} 13^{\prime} 06.0^{\prime \prime} \mathrm{W}\right)$, urban area; Porto Alegre, Parque Maurício

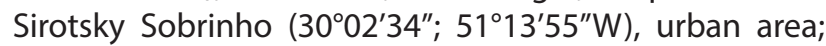
Porto Alegre, UFRGS/Campus do Vale (3004'12.4"S; $\left.51^{\circ} 07^{\prime} 06.9^{\prime \prime} \mathrm{W}\right)$, urban area; Porto Alegre, Parque Gabriel Knijnick (3006 $\left.12^{\prime \prime} \mathrm{S} ; 5^{\circ} 12^{\prime} 08^{\prime \prime} \mathrm{W}\right)$, forest remnant; Pelotas,

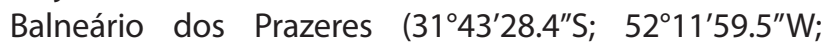
$15 \mathrm{~m}$, and $\left.31^{\circ} 44^{\prime} 06.5^{\prime \prime} \mathrm{S} ; 52^{\circ} 12^{\prime} 54.1^{\prime \prime} \mathrm{W} ; 21 \mathrm{~m}\right)$, urban area;

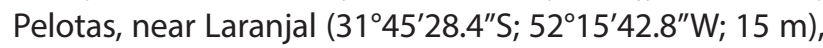
urban area; Pelotas, Fragata $\left(31^{\circ} 45^{\prime} 18.3^{\prime \prime} \mathrm{S} ; 52^{\circ} 23^{\prime} 01.1^{\prime \prime} \mathrm{W}_{\text {; }}\right.$ $62 \mathrm{~m})$, urban area; Pelotas, Fragata, near Arroio Fragata $\left(31^{\circ} 45^{\prime} 29.5^{\prime \prime} \mathrm{S} ; 52^{\circ} 24^{\prime} 05.05^{\prime \prime} \mathrm{W} ; 62 \mathrm{~m}\right)$, urban area. 
Table 1. Host plants for Brazilian restricted flower-breeding species of drosophilids found in the present survey.

\begin{tabular}{|c|c|c|c|c|c|c|c|c|c|c|c|c|}
\hline \multirow{2}{*}{ Plant / Fly } & \multicolumn{8}{|c|}{ D. bromeliae species group } & \multicolumn{2}{|c|}{ D. Iutzii species group } & \multicolumn{2}{|c|}{ genus Zygothrica } \\
\hline & D. bromeliae & D. bromelioides & type III & type III' & type IV & type IV' & type V & type VI & D. denieri & D. Iutzii & Z. dispar & Z. sp.1 \\
\hline \multicolumn{13}{|l|}{ Acanthaceae } \\
\hline Justicia carnea & & & & & & & & & & & $x$ & \\
\hline Thunbergia alata ${ }^{1}$ & & $x$ & & & & & & & & & & \\
\hline Thunbergia grandiflora $^{1}$ & $x$ & $x$ & $x$ & $x$ & & & & & & & $x$ & \\
\hline \multicolumn{13}{|l|}{ Apocynaceae } \\
\hline Allamanda cathartica & & & $x$ & & & & & & & & & \\
\hline Allamanda polyantha & & $x$ & & & & & & & & & & \\
\hline \multicolumn{13}{|l|}{ Aristolochiaceae } \\
\hline Aristolochia gigantea & & $x$ & & & & & & & & & & \\
\hline Asparagaceae & & & & & & & & & & & & \\
\hline Yucca gigantea & & $\mathrm{x}$ & & & & & & & & & & \\
\hline Bignoniaceae & & & & & & & & & & & & \\
\hline Amphilophium cuneifolium & $x$ & & & & & & & & & & & \\
\hline Dolichandra unguis-cati & & $x$ & & & & & & & & & & \\
\hline Handroanthus albus ${ }^{2}$ & & $x$ & & & & & & & & & & \\
\hline Handroanthus heptaphyllus $^{2}$ & & $x$ & & & & & & & & & & \\
\hline Jacaranda mimosifolia ${ }^{2}$ & & $x$ & & & & & & & & & & \\
\hline Jacaranda sp. $^{2}$ & & $x$ & & & & & & & & & $x$ & \\
\hline Pyrostegia venusta & & $x$ & & & & & & & & & & \\
\hline Spathodea campanulata ${ }^{1,2}$ & & $x$ & & & & & & & & & & \\
\hline Tecomastans & & $\mathrm{x}$ & & & & & & & & & & \\
\hline Convolvulaceae & & & & & & & & & & & & \\
\hline Ipomoea alba & & $x$ & $x$ & & & & & & $x$ & & & \\
\hline Ipomoea asarifolia & $x$ & & & & & & & & & & & \\
\hline Ipomoea batatas & & $x$ & & & & & & & & $x$ & & \\
\hline Ipomoea cairica & & $x$ & & & & & & & $x$ & $x$ & $x$ & \\
\hline Ipomoea carnea fistulosa & & $x$ & $x$ & & & & & & & $x$ & & \\
\hline Ipomoea aff. chiliantha & & $x$ & & & & & & & & $x$ & & \\
\hline Ipomoea indica & & $x$ & & & & & & & $x$ & $x$ & & \\
\hline Ipomoea pes-caprae & & $x$ & & & & & & & & $x$ & & \\
\hline Cucurbitaceae & & & & & & & & & & & & \\
\hline Cucurbita pepo $^{1}$ & & $x$ & & & & & & & $x$ & & & \\
\hline Fabaceae & & & & & & & & & & & & \\
\hline Bauhinia variegata $^{1}$ & & $x$ & & & & & & & & & & \\
\hline Erythrina crista-galli ${ }^{2}$ & & $x$ & & & & & & & & & & \\
\hline Wisteria floribunda ${ }^{2}$ & & $x$ & & & & & & & & & & \\
\hline sp.1 & & $x$ & & & & & & & & & & \\
\hline Hypericaceae & & & & & & & & & & & & \\
\hline Hypericum sp.1 & & $x$ & & & & & & & & & & \\
\hline Iridaceae & & & & & & & & & & & & \\
\hline Dietes bicolor ${ }^{1}$ & & $x$ & & & & & & & & & & \\
\hline Malvaceae & & & & & & & & & & & & \\
\hline Abutilon sp. & & $x$ & & & & & & & & & & \\
\hline Ceiba speciosa $a^{2}$ & & $x$ & $x$ & & & & & & & & & \\
\hline Dombeya wallichii ${ }^{1}$ & & $x$ & & & & & & & & & & \\
\hline Hibiscus rosa-sinensis ${ }^{1}$ & $x$ & $x$ & & & & & & & & & & \\
\hline Hibiscus pernambucensis & & $x$ & & & & & & & & & & \\
\hline Hibiscus tiliaceus $^{1}$ & & $x$ & & & & & & & $x$ & & & \\
\hline Malvaviscus penduliflorus & & $x$ & & & & & & & & & & \\
\hline Melastomataceae & & & & & & & & & & & & \\
\hline Tibouchina sp.1 & & $x$ & & & & & & & & & & \\
\hline Musaceae & & & & & & & & & & & & \\
\hline sp.1 & $x$ & & & & & & & & & & & \\
\hline Passifloraceae & & & & & & & & & & & & \\
\hline Passiflora alata & & $x$ & & & & & & & & & & \\
\hline Passiflora edulis & & $x$ & & & & & & & $x$ & & & \\
\hline Solanaceae & & & & & & & & & & & & \\
\hline Brugmansia suaveolens & & $x$ & $x$ & & & & & & $x$ & $x$ & $x$ & \\
\hline Brunfelsia uniflora & & & & & & & & & & & $x$ & \\
\hline Solanum mauritianum & & & & & $x$ & $x$ & & & & & & \\
\hline Solanum paniculatum & & $x$ & & & $x$ & $x$ & $x$ & & & & & \\
\hline Solanum sisymbriifolium & & & & & & & $x$ & & & & & \\
\hline Solanum stramoniifolium & & & & & & & & $x$ & & & & \\
\hline Solanum sanctaecatharinae & & & & & $x$ & & $x$ & & & & & $x$ \\
\hline Solanum sp.2 & & & & & & & $x$ & & & & & \\
\hline Solanum sp.3 & & $x$ & & & & & $x$ & & & & & \\
\hline Tropaeolaceae & & & & & & & & & & & & \\
\hline Tropaeolum majus & & $x$ & & & & & & & & & & \\
\hline Zingiberaceae & & & & & & & & & & & & \\
\hline Hedychium coronarium $^{1}$ & & $x$ & & & & & & & & & & \\
\hline
\end{tabular}

${ }^{1}$ exotic species in Neotropics; ${ }^{2}$ fallen flowers 
Table 2. Host plants for Brazilian species of drosophilids of uncertain biology found in flowers in the present survey.

\begin{tabular}{|c|c|c|c|c|c|c|}
\hline Plant / Fly & C. bupeo & C. sp.1 & R. joaquina & S. sp.1 & S. sp.2 & S. sp.3 \\
\hline \multicolumn{7}{|l|}{ Bignoniaceae } \\
\hline Handroanthus albus ${ }^{2}$ & & & & $\mathrm{x}$ & & \\
\hline Handroanthus heptaphyllus ${ }^{2}$ & & & & $x$ & $x$ & $x$ \\
\hline Pyrostegia venusta & $x$ & & & $x$ & & \\
\hline \multicolumn{7}{|l|}{ Bromeliaceae } \\
\hline Dyckia encholirioides & & & $x$ & & & \\
\hline \multicolumn{7}{|l|}{ Malvaceae } \\
\hline Dombeya wallichii' & & & & $x$ & & \\
\hline Dombeya tiliacea $^{1}$ & & $x$ & & & & \\
\hline
\end{tabular}

${ }^{1}$ exotic species in Neotropics; ${ }^{2}$ fallen flowers

Type III. Santa Catarina: Antônio Carlos, Rachadel (2729'52.8'S; 4847'38.6"W), rural area; Rio Grande do Sul: Porto Alegre, Parque Marinha do Brasil $\left(30^{\circ} 03^{\prime} 16.3^{\prime \prime S}\right.$; $\left.51^{\circ} 13^{\prime} 57.8^{\prime \prime} \mathrm{W}\right)$, urban area; Porto Alegre, UFRGS/Campus do Vale $\left(30^{\circ} 04^{\prime} 12.4^{\prime \prime} \mathrm{S} ; 5^{\circ} 07^{\prime} 06.9^{\prime \prime} \mathrm{W}\right)$, urban area; Pelotas,

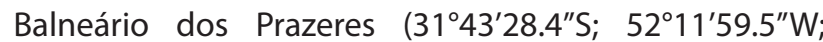
$15 \mathrm{~m})$, urban area.

Type III'. Pernambuco: Recife, UFPE campus (08 $03^{\prime} 14^{\prime \prime}$; $\left.34^{\circ} 57^{\prime} 00^{\prime \prime} \mathrm{W}\right)$, urban area.

Type IV. Santa Catarina: Florianópolis, Córrego Grande (273'37.6"S; 48²9'37.0"W), urban area; Rio Grande do

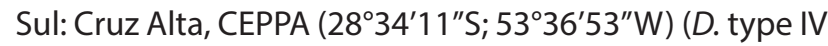
of Hochmüller et al., 2009), forest remnant; Flores da

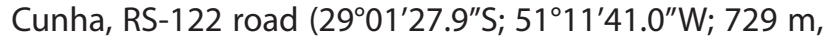
and $29^{\circ} 01^{\prime} 37.4^{\prime \prime}$; ; 51 $11^{\prime} 43.7^{\prime \prime} \mathrm{W} ; 733 \mathrm{~m}$ ), peri-urban area; Porto Alegre, UFRGS/Campus do Vale $\left(30^{\circ} 04^{\prime} 12.4^{\prime \prime}\right.$; $\left.51^{\circ} 07^{\prime} 06.9^{\prime \prime} \mathrm{W}\right)$, urban area.

Type IV'. Bahia: Itaparica, Itaparica Island, (1254'18"S; $\left.38^{\circ} 40^{\prime} 01^{\prime \prime} \mathrm{W}\right)$, peri-urban area; Minas Gerais: Monte Sião, Centro (22 $25^{\prime} 36.16^{\prime \prime} S$; $\left.46^{\circ} 34^{\prime} 10.43^{\prime \prime} W\right)$, urban area; São
Paulo: Águas de Lindóia, Morro do Cruzeiro (22²8'43"S; 46 37'34"W), peri-urban area; Paraná: São José dos Pinhais, Águas Belas (2532'09.71"S; 49¹0'52.87"W), urban area; Santa Catarina: Antônio Carlos, Rachadel (2729'48.02"S; 4847'39.70"W), rural area.

Type V. Santa Catarina: Florianópolis, Córrego Grande (27³5'37.6"S; 48²9'37.0"W), urban area; Rio Grande do Sul: Porto Alegre, UFRGS/Campus do Vale (3004'12.4"S; $\left.51^{\circ} 07^{\prime} 06.9^{\prime \prime} \mathrm{W}\right)$, urban area; Pelotas, Balneário dos Prazeres $\left(31^{\circ} 43^{\prime} 28.4^{\prime \prime} \mathrm{S} ; 52^{\circ} 11^{\prime} 59.5^{\prime \prime} \mathrm{W} ; 15 \mathrm{~m}\right.$, and $31^{\circ} 44^{\prime} 06.5^{\prime \prime} \mathrm{S}$; $\left.52^{\circ} 12^{\prime} 54.1^{\prime \prime} \mathrm{W} ; 21 \mathrm{~m}\right)$, urban area.

TypeVI.Pará:Belém, Reserva do Mocambo (01²6'34.35"S; $\left.48^{\circ} 24^{\prime} 35.59^{\prime \prime} \mathrm{W} ; 40 \mathrm{~m}\right)$, natural Amazon forest.

\section{Drosophila lutzii species group (= subgenus Phloridosa Sturtevant of Drosophila)}

Drosophila denieri Blanchard. Santa Catarina: Antônio

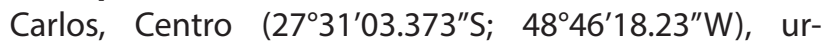
ban area; Florianópolis, Ponta do Coral (27⒊'23"S; $\left.48^{\circ} 31^{\prime} 41^{\prime \prime} \mathrm{W}\right)$, urban area; Rio Grande do Sul: Caxias do

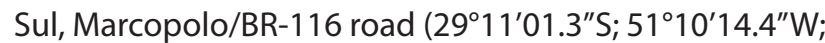
$701 \mathrm{~m}$, and 29 $11^{\prime} 06.4^{\prime \prime S}$; 51¹0'23.8"W; $695 \mathrm{~m}$ ), urban area; Porto Alegre, Parque Maurício Sirotsky Sobrinho (3002'34"; 51 $\left.13^{\circ} 55^{\prime \prime} \mathrm{W}\right)$, urban area; Porto Alegre,

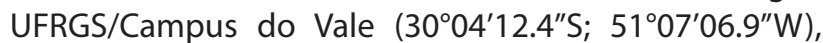
urban area; Pelotas, Fragata $\left(31^{\circ} 45^{\prime} 18.3^{\prime \prime} ; 52^{\circ} 23^{\prime} 01.1^{\prime \prime} \mathrm{W}\right.$; $62 \mathrm{~m})$, urban area; Pelotas, Fragata, near Arroio Fragata $\left(31^{\circ} 45^{\prime} 29.5^{\prime \prime} \mathrm{S} ; 52^{\circ} 24^{\prime} 05.05^{\prime \prime} \mathrm{W} ; 62 \mathrm{~m}\right)$, urban area.

Drosophila lutzii Sturtevant. São Paulo: Águas de

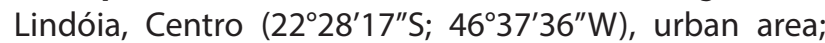
Águas de Lindóia, Morro do Cruzeiro (22²8'43"S; 46³7'34"W), peri-urban area; Paraná: Guarapuava, Parque do Lago $\left(25^{\circ} 24^{\prime} 9.099^{\prime \prime}\right.$; $\left.5^{\circ} 28^{\prime} 30.82^{\prime \prime} \mathrm{W}\right)$, urban area; Santa Catarina: Governador Celso Ramos,

Table 3. Host plants for Brazilian opportunistic species of drosophilids found in flowers in the present survey.

\begin{tabular}{|c|c|c|c|c|c|c|c|c|c|c|}
\hline Plant / Fly & D. cardinoides & D. griseolineata & D. mediostriata & D. mediovittata & D. melanogaster ${ }^{1}$ & D. paulistorum & D. simulans ${ }^{7}$ & D. sticta & $\begin{array}{c}\text { D. tripunctata } \\
\text { gr. sp.1 }\end{array}$ & Z. indianus ${ }^{1}$ \\
\hline \multicolumn{11}{|l|}{ Acanthaceae } \\
\hline Thunbergia grandiflora ${ }^{1}$ & & & & & $x$ & & & & & \\
\hline \multicolumn{11}{|l|}{ Apocynaceae } \\
\hline Allamanda polyantha & & & & & & $x$ & & & & \\
\hline \multicolumn{11}{|l|}{ Aristolochiaceae } \\
\hline Aristolochia gigantea & & & & & $x$ & & & & & \\
\hline \multicolumn{11}{|l|}{ Asparagaceae } \\
\hline Yucca gigantea ${ }^{2}$ & & & & & & & $x$ & & & $x$ \\
\hline \multicolumn{11}{|l|}{ Bignoniaceae } \\
\hline Handroanthus albus ${ }^{2}$ & & $x$ & & & & & & $x$ & & \\
\hline Handroanthus heptaphyllus ${ }^{2}$ & & & & $x$ & & & $x$ & & & \\
\hline \multicolumn{11}{|l|}{ Fabaceae } \\
\hline Erythrina speciosa $^{2}$ & & & & & & & & & $x$ & \\
\hline \multicolumn{11}{|l|}{ Malvaceae } \\
\hline Ceiba speciosa $a^{2}$ & $x$ & & & & & & & $x$ & & \\
\hline Hibiscus pernambucensis $^{2}$ & & & $x$ & & & & & & & \\
\hline
\end{tabular}


Anhatomirim Island (27²5'38.09"S; 48³3'53.89"W), border of natural Atlantic forest; Florianópolis, UFSC campus $\left(27^{\circ} 36^{\prime} 08.127^{\prime \prime} S\right.$; $\left.48^{\circ} 31^{\prime} 30.39^{\prime \prime} \mathrm{W}\right)$, urban area; Rio Grande do Sul, Caxias do Sul, Marcopolo/BR-116

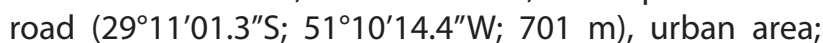
Rio Grande do Sul: Porto Alegre, Parque Maurício Sirotsky Sobrinho $\left(30^{\circ} 02^{\prime} 34^{\prime \prime}\right.$; ; $\left.51^{\circ} 13^{\prime} 55^{\prime \prime} \mathrm{W}\right)$, urban area; Porto Alegre, UFRGS/Campus do Vale $\left(30^{\circ} 04^{\prime} 12.4^{\prime \prime}\right.$; $\left.51^{\circ} 07^{\prime} 06.9^{\prime \prime} \mathrm{W}\right)$, urban area. First records for São Paulo and Paraná states.

\section{Genus Zygothrica Wiedemann}

Zygothrica dispar (Wiedemann). Santa Catarina: Florianópolis, Morro da Lagoa da Conceição (27³5'40.9"S; $\left.48^{\circ} 28^{\prime} 41.6^{\prime \prime} \mathrm{W} ; 200 \mathrm{~m}\right)$, natural Atlantic forest; Rio Grande do Sul: Porto Alegre, UFRGS/Campus do Vale $\left(30^{\circ} 04^{\prime} 12.4^{\prime \prime} \mathrm{S} ; 51^{\circ} 07^{\prime} 06.9^{\prime \prime} \mathrm{W}\right)$, urban area. 49 specimens.

Zygothrica sp.1. Rio Grande do Sul: Porto Alegre, UFRGS/ Campus do Vale $\left(30^{\circ} 04^{\prime} 12.4^{\prime \prime}\right.$; $\left.51^{\circ} 07^{\prime} 06.9^{\prime \prime} \mathrm{W}\right)$, urban area. Six specimens.

\section{(2) “Uncertain biology”}

Cladochaeta bupeo Grimaldi \& Nguyen. Rio Grande do Sul: Porto Alegre, UFRGS/Campus do Vale $\left(30^{\circ} 04^{\prime} 12.4^{\prime \prime S}\right.$; $\left.51^{\circ} 07^{\prime} 06.9^{\prime \prime} \mathrm{W}\right)$, urban area. First record for South America and new southernmost locality. Three specimens.

Cladochaeta sp.1. (Cladochaeta nebulosa species group). Rio Grande do Sul: Porto Alegre, Parque Farroupilha $\left(30^{\circ} 02^{\prime} 13.0^{\prime \prime} \mathrm{S} ; 51^{\circ} 13^{\prime} 06.0^{\prime \prime} \mathrm{W}\right)$, urban area. Two specimens.

Rhinoleucophenga joaquina Schmitz et al. Santa Catarina: Florianópolis, Parque Municipal das Dunas da Lagoa da Conceição, Joaquina $\left(27^{\circ} 38^{\prime} \mathrm{S} ; 4^{\circ} 28^{\prime} \mathrm{W}\right)$, natural restinga/sandy dunes. Seven specimens. New species: this is the sample on which the taxonomic description was based.

Scaptomyza sp.1. (subgenus Mesoscaptomyza Hackman). Rio Grande do Sul: Porto Alegre, Parque da Marinha (3003'40.75"S; 51 $\left.13^{\prime} 40.75^{\prime \prime} \mathrm{W}\right)$; Porto Alegre, UFRGS/Campus do Vale (3004'12.4"S; 51 $\left.{ }^{\circ} 07^{\prime} 06.9^{\prime \prime} \mathrm{W}\right)$, urban area. 36 specimens.

Scaptomyza sp.2. (subgenus Parascaptomyza Duda). Rio Grande do Sul: Porto Alegre, UFRGS/Campus do Vale $\left(30^{\circ} 04^{\prime} 12.4^{\prime \prime} \mathrm{S} ; 51^{\circ} 07^{\prime} 06.9^{\prime \prime} \mathrm{W}\right)$, urban area. 26 specimens.

Scaptomyza sp.3. (subgenus Mesoscaptomyza). Rio Grande do Sul: Porto Alegre, UFRGS/Campus do Vale $\left(30^{\circ} 04^{\prime} 12.4^{\prime \prime} \mathrm{S} ; 51^{\circ} 07^{\prime} 06.9^{\prime \prime} \mathrm{W}\right)$, urban area. 15 specimens.

\section{(3) "Opportunists"}

Drosophila cardinoides Dobzhansky \& Pavan. Rio Grande do Sul: Porto Alegre, UFRGS/Campus do Vale $\left(30^{\circ} 04^{\prime} 12.4^{\prime \prime} \mathrm{S} ; 51^{\circ} 07^{\prime} 06.9^{\prime \prime} \mathrm{W}\right)$, urban area. 150 specimens.
Drosophila griseolineata Duda. Rio Grande do Sul: Porto Alegre, UFRGS/Campus do Vale $\left(30^{\circ} 04^{\prime} 12.4^{\prime \prime} \mathrm{S}\right.$; $\left.51^{\circ} 07^{\prime} 06.9^{\prime \prime} \mathrm{W}\right)$, urban area. One specimen.

Drosophila mediostriata Duda. Santa Catarina: Florianópolis, Ponta do Coral $\left(27^{\circ} 34^{\prime} 23^{\prime \prime S}\right.$; 48 $\left.31^{\prime} 41^{\prime \prime} \mathrm{W}\right)$, urban area.

Drosophila mediovittata Frota-Pessoa. Rio Grande do Sul: Porto Alegre, UFRGS/Campus do Vale (3004'12.4"S; $\left.51^{\circ} 07^{\prime} 06.9^{\prime \prime} \mathrm{W}\right)$, urban area. One specimen.

Drosophila melanogaster Meigen. Pernambuco: Recife, UFPE campus (080.'14"S; $34^{\circ} 57^{\prime} 00^{\prime \prime} \mathrm{W}$ ), urban area; Santa Catarina: Florianópolis, UFSC campus (27³6'08.127"S; $\left.48^{\circ} 31^{\prime} 30.39^{\prime \prime} \mathrm{W}\right)$, urban area. Six specimens.

Drosophila paulistorum Dobzhansky \& Pavan. Rio Grande do Sul: Porto Alegre, UFRGS/Campus do Vale $\left(30^{\circ} 04^{\prime} 12.4^{\prime \prime} \mathrm{S} ; 51^{\circ} 07^{\prime} 06.9^{\prime \prime} \mathrm{W}\right)$, urban area. 26 specimens.

Drosophila simulans Sturtevant. Rio Grande do Sul: Porto Alegre, UFRGS/Campus do Vale (3004'12.4"S; $\left.51^{\circ} 07^{\prime} 06.9^{\prime \prime} \mathrm{W}\right)$, urban area. 8 specimens.

Drosophila sticta Wheeler. Santa Catarina: Antônio Carlos, Centro (27³1'03.373"S; 48 46'18.23"W), urban area; Rio Grande do Sul: Porto Alegre, UFRGS/Campus do Vale $\left(30^{\circ} 04^{\prime} 12.4^{\prime \prime}\right.$; $\left.51^{\circ} 07^{\prime} 06.9^{\prime \prime} \mathrm{W}\right)$, urban area. Four specimens.

Drosophila tripunctata group sp.1. Rio Grande do Sul: Porto Alegre, Parque Farroupilha (3002'13.0"S; $\left.51^{\circ} 13^{\prime} 06.0^{\prime \prime} \mathrm{W}\right)$, urban area. One specimen.

Zaprionus indianus Gupta. Rio Grande do Sul: Porto Alegre, Parque Farroupilha ( $\left.30^{\circ} 02^{\prime} 13.0^{\prime \prime} \mathrm{S} ; 51^{\circ} 13^{\prime} 06.0^{\prime \prime} \mathrm{W}\right)$, urban area. 22 specimens.

\section{DISCUSSION}

The flower-breeding drosophilid fauna of Brazil proved to be strikingly unknown. Out of the 28 species found, 12 species were of unknown identity and probably still undescribed at the moment of collection, i.e., $\sim 43 \%$. The ignorance in respect to this fauna is still more pronounced if one disregards the opportunist fruit-breeding species and considers only the exclusive fauna associated with flowers ("restricted" and "uncertain biology" categories): 12 undescribed species out of 18, i.e., two-thirds of them. Undescribed species of drosophilids in Brazilian fauna are not uncommon, even in surveys based on banana-baited traps. Medeiros \& Klaczko (2004) estimated that half of the Drosophila species of the state of São Paulo, the best sampled Brazilian state, was still undescribed. A high number of undescribed species was also collected in Santa Catarina, another relatively well-studied state, by Gottschalk et al. (2007) and Döge et al. (2008). The diversity of flower-breeding 
drosophilids, although clearly lower than those associated with fruits, appears to be even more unknown. This is especially astonishing considering that Drosophilidae is one of the most studied taxa of Diptera. Brown (2005) estimated that for the largest Diptera families, the rate of newly described species is only 7.6 per year in the Neotropical region, and more than 1,000 years would be necessary to describe all species of Diptera in the world. Furthermore, a described species does not mean necessarily a well-known species: several described species found in the present survey are recorded for the first time in some Brazilian states or even in South America. In fact, drosophilid records in Brazil are strongly biased towards fruit-feeding species of Drosophila, and to southeastern and southern localities (more exactly, near the main universities, and the present survey is no exception); moreover, about one third of the species recorded in Brazil is known for a single locality (Gottschalk et al., 2008). Some new anthophilic species were described recently for Neotropics (Vaz et al., 2014, 2018; Grimaldi, 2016; Llangarí \& Rafael, 2017; Vilela \& Prieto, 2018), but none of them seem to be conspecific with the species of unknown identity reported in the present survey.

Although a few samples of the present survey were taken from natural areas, most of them came from urban or peri-urban environments, including 10 of the 12 probably undescribed species and the two new records for Brazil. Despite the importance of studying biodiversity in the natural environments, as stated by Hartop et al. (2015), "we need not travel far to have plentiful opportunities for studying biodiversity". As an example, in the present survey, seven undescribed species and one new record for South America were found in the Campus do Vale of the Federal University of Rio Grande do Sul (UFRGS), in the city of Porto Alegre, which is where is situated the Drosophila laboratory led by one of us (VLSV) and whose team has been studying urban drosophilid assemblages since the decade of 1980, although focusing on the frugivore guild (e.g., Valente et al., 1989; Garcia et al., 2012). This fact stresses once more the enormous taxonomic deficiency, including for relatively well studied taxa of insects, and the importance of studies on taxonomy, diversity inventories and monitoring in the rapidly changing urban environments to understand the biotic changes, including the introductions and extinctions that will occur in the future (Hartop et al., 2016). It is noticeable that some of the fly species reported in the present survey showed to be able to colonize flowers of cultivated and exotic plants. Exotic flower-breeding drosophilids have recently been reported for Los Angeles, USA (Grimaldi et al., 2014).

\section{The restricted flower-breeding species}

The species included here are thought to breed exclusively or preferentially in flowers. They are never or rarely attracted to fruit-baited traps. They were found exclusively or mostly in living flowers and belong to taxa whose flower-breeding niche is well-established for the Neotropics (Brncic, 1983; Grimaldi, 1987). In this category were included the six species of the $D$. bromeliae group, the two species of the $D$. lutzii group and the two species of the genus Zygothrica. These taxa were found again when collections of the same host plant in the same locality were repeated.

\section{Drosophila bromeliae species group}

This group showed to be the most speciose, abundant and widespread, found in all sites surveyed (Fig. 1) and also the more taxonomically challenging. Altogether, eight species were found. All these species are cryptic with regard to external morphology but can be discriminated by aedeagus morphology. In the time of sampling, just five species of $D$. bromeliae species group were described, and descriptions of terminalia were not available for the two species described by Sturtevant $(1916,1921)$. This impeded the recognition if any of the species found were conspecific to Sturtevant's species and, therefore, which of them represented new species. Just $D$. bromelioides specimens could be clearly recognized based on the male terminalia of the lectotype depicted by Val (1982). After Grimaldi (2016) redescribed the Sturtevant's specimens, another of the species found in this survey could be recognized as $D$. bromeliae. The identity of the six other species found here deserves a more careful study since there are subtle to great differences in the morphology of aedeagus from all the other described species, including the nine new species described by Grimaldi (2016) based mostly on Central American specimens. They are mentioned herein as types III, III', IV, IV', $\mathrm{V}$ and VI.

The species found in the present survey showed marked differences in host species (Table 1), from broad generalist to ecologically specialized species. Individuals of the polyphagous species started to emerge from flowers around 10-13 days after the field collection. The Solanum-specialized species takes a little longer, around 13-16 days.

Drosophila bromelioides was the most conspicuous species and proved to be widely generalist, recorded in 42 host species, from 16 botanical families. Although rarely, this species is sometimes caught at low numbers even in banana-baited traps (De Toni et al., 2007; Gottschalk et al., 2007; Schmitz et al., 2007) and under constant attention can be reared in a banana-agar medium in the laboratory. However, flowers are clearly its preferred breeding site. It was found in southern localities, in the states of Rio Grande do Sul, Santa Catarina, Paraná, and São Paulo. Other studies have recorded it also in other south-central Brazil localities (Vilela \& Mori, 1999; Chaves \& Tidon, 2008; Roque \& Tidon, 2008). A morphologically similar species, D. bromeliae, was found in northern Brazilian localities (Pará, Pernambuco and Mato Grosso states) in the present study and reported to Caribbean, Central America, and Ecuador by Grimaldi (2016). This is the first confirmed record of the species in Brazil. Although some earlier studies reported $D$. bromeliae or $D$. bromelioides in other localities, caution is needed, due to the cryptic diversity revealed here and by Grimaldi (2016). As ex- 
amples, there are records for $D$. bromeliae in Campos do Jordão (São Paulo) by Hsu (1949) and D. bromelioides in Salvador (Bahia) by Malogolowkin (1951). However, both precede the first description of aedeagus for D. bromelioides (Val, 1982) and for D. bromeliae (Grimaldi, 2016), so, it is advisable to treat these and other cases as doubtful. Based on the results of the present survey, D. bromeliae is probably also a polyphagous species, found in five host species, of five families, and also can be reared in the banana-agar medium. As our sampling effort in northern Brazilian regions was lower, these numbers cannot be directly compared to those of $D$. bromelioides. Future samplings in the region are necessary to clear the extent of the niche breadth of this species. It is probable that various other hosts can be found.

Based on aedeagus morphology, types III and III' are thought to be closely related species. Type III was found in the southern states of Rio Grande do Sul and Santa Catarina, while the type III' was found in the northeastern state of Pernambuco. Although also polyphagous, being found in six host species from five families, type III exploits a smaller variety of host plants compared to the sympatric $D$. bromelioides. In turn, the type III' was found in only one host species, being more restricted than the sympatric species D. bromeliae. However, future sampling probably must find other host plants for it, since it was discovered breeding in Thunbergia grandiflora, which is a cultivated exotic plant. Presumably, it may occupy a similar niche to its southern sibling type III, i.e., polyphagous but not as generalist as $D$. bromelioides and $D$. bromeliae. Both types III and III' can be reared, although not easily, in banana-agar medium in laboratory.

In southern localities, D. bromelioides and type III can occur is some hosts both syntopically and synchronically, although seemingly with some different preferences. A great number of type III specimens were reared from Brugmansia suaveolens, where it generally outnumbered $D$. bromelioides. Ipomoea alba was an exception in its genus for apparently representing an important host for type III, whereas other species of the genus host almost exclusively $D$. bromelioides. The type III' was also found co-occurring with the more generalist D. bromeliae in Thunbergia grandiflora flowers in Pernambuco. All four species showed to be able to breed in some exotic plants.

In contrast to their more generalist siblings, four more specialized species complete the group, all of them exclusively using species of Solanum as host species. Despite some effort, none of these species could be reared in artificial culture media in laboratory, even when some kind of Solanum flower juice was added to the medium. These species are being called here as types IV, IV', V and VI.

The types IV and IV' are morphologically similar. Type IV was found in the southern states of Rio Grande do Sul and Santa Catarina, while the type IV' was found in Bahia, Minas Gerais, São Paulo, Paraná, and Santa Catarina. Additionally, the type $\mathrm{V}$ was also found in the southern states of Rio Grande do Sul and Santa Catarina. These species share some hosts with type IV, although the two species seem to have some different host pref- erences. Both species breed in Solanum paniculatum, sometimes from the same plant; on the other hand, type IV occurs solely in S. mauritianum, while type $\mathrm{V}$ is the only found in S. sisymbriifolium in these localities. Other Solanum species were less sampled, but both fly species shared S. sanctaecatharinae. The type V showed to have a slightly wider niche, being found in six species of Solanum, while type IV was found in three species. Some specimens of the generalist $D$. bromelioides were reared from Solanum flowers, but only in a few occasions and at low numbers, suggesting that this genus does not represent a main host for it. Finally, in a sample taken in the northern state of Pará, another species was found, the type VI. Its host plant, S. stramoniifolium does not occur in southern Brazil.

Solanum is a large and worldwide distributed genus, especially in tropical and subtropical regions (Mentz \& Oliveira, 2004). Species sampled in the present survey are native from Neotropics and are mostly ruderal plants, occurring on pioneer types of vegetation, at roadsides, field and forest borders. However, no equivalent Solanumspecialized drosophilid is known in other parts of the world. The only literature record known by us is on the occurrence of Scaptodrosophila minimeta (Bock) in flowers of S. torvum and S. mauritianum in Australia (Bock \& Parson, 1981), but the ecology of this species is poorly known. It can be inferred that this species uses other natural resources, as both species of Solanum are native from the Neotropics and introduced to Australia.

The records presented here suggest the existence of pairs of morphologically and ecologically similar species in different localities in Brazil, in each case with one of them found in northern localities and another in southern localities (the generalist $D$. bromeliae and $D$. bromelioides, the oligophagous types III' and III, the Solanumspecialized types IV' and IV, respectively with a northern and a southern distribution). Though, since our sampling in the huge Brazilian territory and plant biodiversity was not exhaustive and was biased to southern localities, this preliminary observation needs to be tested by future studies.

\section{Drosophila lutzii species group (= subgenus Phloridosa of Drosophila)}

This taxon comprises only Neotropical flower-breeding species, traditionally classified as the subgenus Phloridosa (Sturtevant, 1942), but recently transferred to the subgenus Drosophila as D. lutzii species group (Yassin, 2013). Two species were represented in our samples, $D$. denieri and $D$. lutzii. Their time of emergence of imagoes was around 10-13 days after the flowers were collected. Drosophila lutzii are widespread in the Southern United States, Mexico, Central America (Sturtevant, 1921; Chassagnard \& Tsacas, 1992), and introduced to Hawaii (Montague \& Kaneshiro, 1982), but only sparsely recorded in South America (Pilares \& Suyo, 1982, in Peru; Vilela, 1984, in Argentina; Acurio \& Rafael, 2009, in Ecuador), although probably widespread. It was recorded in Brazil for the first time by Schmitz \& Hofmann (2005), in the 
southern states of Rio Grande do Sul and Santa Catarina, followed by Roque \& Tidon (2008) in the states of Mato Grosso and Goiás, in central Brazil, and Santa-Brígida et al. (2017) in the northern state of Pará. In the present survey, it is recorded for the first time in the states of São Paulo and Paraná. In turn, D. denieri is known only to South America, being referred for northern Argentina (Blanchard, 1938), Uruguay (Goñi et al., 1998) and for the Brazilian states of Rio Grande do Sul, Santa Catarina (Schmitz \& Hofmann, 2005), Rio de Janeiro (Frota-Pessoa, 1952) and Mato Grosso (Blauth \& Gottschalk, 2007). Both species are polyphagous. In the present survey, while $D$. denieri occurred in a wider variety of botanical families, including exotic elements, most specimens of $D$. Iutzii occurred in Ipomoea. However, this species is also recorded for different botanical families (Chassagnard \& Tsacas, 1992; Roque \& Tidon, 2008). The two species co-occurred in Brugmansia suaveolens, but generally, $D$. denieri was the most common species in this plant. On the other hand, D. lutzii was the most common species found in all species of Ipomoea, except I. alba. However, there are exceptions, such as Pelotas, where only $D$. denieri was found in I. cairica and I. indica. These two species, wherever found, almost always shared their host plants with species of the Drosophila bromeliae species group. Both species could be reared just very poorly in the banana-agar medium in the laboratory, with just a few individuals for one generation or two, as previously reported for the group (Brncic, 1962b).

\section{Zygothrica}

It is reported that great numbers of adult flies of this genus can be found over bracket fungi in rainforests, but the kind of relation between flies and fungi is questionable. Undoubtedly, fungi actually represent breeding sites for some Zygothrica species (Grimaldi, 1987; Roque et al., 2006; Valer et al., 2016), but Grimaldi (1987) suggested that in many cases they are used only as rendez-vous sites. Indeed, several records for breeding sites in the genus are flowers, although they are reported only for a few species (Grimaldi, 1987; Fonseca et al., 2017). Zygothrica dispar is a good example of this behavior: Burla (1954) stated that flies of this species were caught by sweeping a net over numerous fungi, but Frota-Pessoa (1952), Malogolowkin (1952), and Santos \& Vilela (2005) reared the species from flowers. It was suggested before (Malogolowkin, 1952; Santos \& Vilela, 2005) that this species is mainly a ground-feeder, opportunistically using fallen flowers. Going against that, in our samples, it was reared mainly from flowers that were collected alive. Time for emergence was around 15-18 days. It demonstrated a preference for forested environments, being, in fact, the main flower-breeding species in the area of Atlantic Forest of Morro da Lagoa da Conceição, Florianópolis. The other species, Z. sp.1, was reared only from Solanum flowers (also collected alive). Interestingly, this situation is analogous with that found in the Drosophila bromeliae species group, with Solanum again requiring a specialized performance.

\section{Species of uncertain biology}

The nature of the interaction between the species included in the category "uncertain biology" and flowers of the host plants recorded in this survey is doubtful. It includes three species of Scaptomyza, two species of Cladochaeta and one species of Rhinoleucophenga. In all instances, collections of the same host plants in the same localities were repeated, but none of these taxa were found again, suggesting that such interactions are not constant. The published records of association of these genera with both flowers or fruits in Neotropics are just scattered or absent, and other ecological niches are reported (leaf-miners, arthropod predators). If they are not specialized breeders in flowers, they may occupy still another unknown niche.

Both species of Cladochaeta found belong to the C. nebulosa species group. Cladochaeta bupeo was known previously only by a few individuals from Panama, collected during the decades of the 1950s and 1960s (Grimaldi \& Nguyen, 1999). This finding represents, therefore, its first record in South America and its new southernmost locality (Porto Alegre, Rio Grande do Sul). The other species, C. sp.1, certainly is a related species, although undescribed. Cladochaeta remains a poorly-known genus in Brazil, as emphasized by Grimaldi \& Nguyen (1999) in their extensive revision of the genus and by recent advances made by Pirani \& Amorim (2016). The authors of both studies expect that many species of this genus remain to be recorded or described from Brazilian territory. The natural history of this genus remains obscure, but larvae of some species are reported to feed on immature stages of other arthropods (Grimaldi \& Nguyen, 1999; Carvalho-Filho et al., 2018). A few cases of association between Cladochaeta and flowers are scatterly reported: between $C$. floridana (Malloch) and Bidens pilosa (Asteraceae) in Florida, USA, between C. psychotria Grimaldi \& Nguyen and Psychotria chiriquiensis (Rubiaceae) in Costa Rica (Grimaldi \& Nguyen, 1999), and between C. aff. paradoxa and Cestrum sendtnerianum (Solanaceae) in São Paulo, Brazil (Santos \& Vilela, 2005). The possibility that these records and the new ones here reported represent specimens that just reached flowers to pupate after feeding on another resource cannot be discarded. The two species found in Porto Alegre were represented only by two and three individuals, respectively, which emerged 12-13 days after the flowers were collected, and were not found again in subsequent samples from the same plants.

The genus Rhinoleucophenga Hendel was represented by one species found in Florianópolis, still undescribed in the occasion. Based on the seven specimens caught, it was subsequently described as $R$. joaquina (Schmitz et al., 2009). Its life cycle is considerably longer than other drosophilids reported here, as imagines took 20-21 days to emerge after the field collection of the flowers. Similarly to Cladochaeta, the natural history of Rhinoleucophenga is also poorly understood, but there are reports of larvae showing predacious behavior on other insects (Costa Lima, 1935; Vidal et al., 2018). So, 
the possibility that such specimens were attacking other insects near or inside the flowers cannot be discarded. A subsequent attempt to collect it from the same plant and locality was unsuccessful, but a few specimens were sampled in banana-baited traps in Bahia and Rio Grande do Sul (Poppe et al., 2015).

Although being one of the larger genera of Drosophilidae, Scaptomyza is virtually ignored in Brazil, with just three described species recorded (Gottschalk et al., 2008). Three species were found in Porto Alegre and probably represent undescribed species. The time for the emergence of imagoes after collection ranged from 11 to 14 days for all species. Scaptomyza sp.1 (36 specimens) and S. sp.3 (15 specimens) belong to subgenus Mesoscaptomyza, while S. sp.2 (26 specimens) belongs to the subgenus Parascaptomyza. Specimens of this genus were mainly found during late winter of 2006, in the flowering period of some Bignoniaceae, but were not found thereafter, even in the same host plants. Although the biology of the genus is not wholly understood, some species of Scaptomyza are known to be important flower breeders, especially in Hawaii, but can also feed on sap flood or leaves (Montague \& Kaneshiro, 1982; Magnacca et al., 2008). In Brazil, Santos \& Vilela (2005) reported one individual of Scaptomyza sp. from flowers of Cestrum sendtnerianum (Solanaceae), in São Paulo.

\section{Opportunist species}

Finally, nine species of Drosophila and one of Zaprionus are presented here as "opportunists", since they are not supposed to present ecological niches strictly linked to flowers. Most of them are known to be fruit-breeding species and, in the present survey were found exclusively from fallen flowers and in just one or two isolated occasions, even when the same host plants were collected again in the same locality. Species that are common members of the Neotropical fruit assemblages of drosophilids (De Toni et al., 2001; Silva et al., 2005; Valadão et al., 2019) and are usually attracted to fruit-baited traps (Tidon, 2006; De Toni et al., 2007; Gottschalk et al., 2007; Garcia et al., 2012), are D. cardinoides, D. griseolineata, D. mediostriata, D. paulistorum, D. melanogaster, D. simulans and Zaprionus indianus, the last three being exotic species. The only specimen classified as $D$. tripunctata gr. sp. 1 was a female from $D$. tripunctata species group, not identified at the species level, since there are a lot of cryptic species in the group, discriminated only by the males, but probably also fits this situation. Except for D. melanogaster and D. paulistorum, all of these species were reared exclusively from fallen flowers. They constitute a substrate very distinct from living flowers, requiring a less specialized performance (Brncic, 1983), giving opportunities for generalist species, which Pipkin et al. (1966) called "ground-feeders". Furthermore, the specimens of $D$. paulistorum reared from living flowers of Allamanda polyantha presented a strikingly reduced body size, suggesting that they passed the pre-adult stage at suboptimal conditions. Interestingly, specimens of $D$. melanogaster reared from living flowers of Thunbergia grandiflora (from Recife) presented a brown-like phenotype. Other evidence that suggests that these species use flowers only as a secondary or incidental host is the fact that they were not found repeatedly in such hosts. Drosophila cardinoides was abundantly reared $(n>100)$ in Porto Alegre from fallen flowers of Ceiba speciosa in late Summer of 2007, which demonstrates its ability to exploit such resource, but no other individual was found in subsequent samples of the same tree, even in the same site, indicating that this association is not constant. Other species were found in lower numbers (normally $n<10$ ). The only of these species found repeatedly in a host plant was $D$. mediostriata in fallen flowers of Hibiscus pernambucensis. This species is, nevertheless, also reared from fruits (Heed, 1957; De Toni et al., 2001), although its presence in flowers was already reported (Dobzhansky \& Pavan, 1950; Pipkin et al., 1966). Unusually, Schmitz et al. (2007) found this species abundantly in banana baited traps at mangrove forests of Santa Catarina Island, southern Brazil, contrasting with very lower abundances in similar surveys in other environments of the same region (De Toni et al., 2007; Gottschalk et al., 2007; Bizzo et al., 2010). Hibiscus pernambucensis is one of the main floristic components of peripheral areas of the mangroves in southern Brazil. However, D. mediostriata oviposits exclusively in fallen flowers, since only $D$. bromelioides was reared from samples of living flowers, showing a clear niche separation of the two species in the flowers of this plant.

The remaining two species are less common in diversity surveys, but still, there is evidence that they are not specialized in flowers. Drosophila mediovitatta was already reported from flowers before, but also from rotten cladodes (Goñi et al., 1998) and from fungi (Gottschalk et al., 2009), this last record in the same locality of the present study (Porto Alegre). Finally, D. sticta was also recorded from flowers before (Pipkin et al., 1966; Santos \& Vilela, 2005), but also in banana-baited traps (Medeiros \& Klaczko, 2004; Garcia et al., 2012).

\section{Future directions}

Since the most representative taxa found in the present survey are known to be widespread in Neotropics, the discovery of the cryptic diversity and the new insect-plant interactions presented here may have broad implications to the knowledge of the Drosophilidae diversity in other Neotropical countries. For example, the discovery of undescribed Solanum-specialized drosophilids both in southern and northern localities in Brazil is very suggestive that such interaction may be more widespread in Neotropics, and so, Solanum should be a target-taxon to be investigated in other countries as well. Furthermore, our sampling was far from exhaustive, and biased to southern localities. The huge territorial extension of Brazil and the extremely high spatial heterogeneity and diversity of flora make a complete assessment of the flower-breeding diversity of drosophilids a challenging task. So, there is a high demand for new efforts in searching for flower-breeding drosophilids in Brazil 
and Neotropical Region as a whole, widening both the range of geographical localities and the diversity of flora surveyed as potential hosts. Several other Drosophilidae taxa not sampled in the present survey are known to be flower-breeding in Neotropical region, as the $D$. onychophora and D. xanthopallescens species groups, additional species of the $D$. bromeliae and $D$. lutzii species groups and some species associated to Araceae. Even the Drosophila flavopilosa species group, a comparatively better-studied taxon and not targeted here, still requires better understanding. Surveys on Drosophilidae diversity are still highly needed, and alternative methods of sampling must be considered besides the traditional banana-baited traps and fallen fruits. Collecting drosophilids from flowers is a relatively simple and cheap method, so it is not difficult to be included in diversity inventories. On the other hand, as shown here, the taxonomic impediment is still very high and probably the most prohibitive challenge for new researches. It is quite certain that many Neotropical flower-breeding species still wait being discovered and integrative taxonomy that links morphological and molecular characters will be probably needed to guide the understanding of species delimitations.

Properly identifying the taxa linked to flowers in a satisfactory biogeographical and ecological framework is a prerequisite to elucidate episodes of host shifts and the repeated evolution of flower-breeding habits within family Drosophilidae. Understanding the natural history of these insects may provide important highlights on the evolution of specialization to host plants. The nature of the insect/plant interaction remains to be unveiled. Reliable information on what exactly the larvae and adults feed on would be welcome. Literature reports on larvae or adults feeding on plant tissues or fluids, pollen or yeasts are more conjectural than empirical. Although a few cases of pollinator drosophilids are known (Sakai, 2002), this may not be the case for most interactions found in the present survey. Solanum, for instance, presents a typical buzz-pollination syndrome, so that the pollen may be assessed only by large bees (Burkart et al., 2014) and not by small insects. Drosophilids are normally primary consumers of microorganisms that colonize plant tissues in early stages of decay (Carson, 1971), and the understanding of the role of microorganisms on the plant-insect interactions is still a main challenge, as the role of potentially toxic plant secondary compounds as selective factors for the adaptive process of colonizing a new host species and the chemosensory mechanisms related to the insect recognition of hosts, especially those with narrower niches (Giron et al., 2018). A multi-disciplinary approach would be essential for giving light to these questions.

The occurrence of species with a broad range of generalist to specialist niches in the Drosophila bromeliae species group, as well as preliminary evidence of differences in the geographical distribution of the species, provides an interesting opportunity to study events of speciation, involving potentially biogeographical or ecological factors.
Studies on tropical assemblages of drosophilids normally are challenged by the huge diversity and complexity of such associations. The study of flower-breeding drosophilids is an opportunity to study the species coexistence through a relatively simpler model. Other ecological, genetic and evolutionary mechanisms could be better understood. As Brncic (1983) stated many years ago, the study of species with restricted niches like the flower-breeding forms is advantageous because it is possible to relate their genetic structure with the ecology under simpler variables, thus allowing a better understanding of the evolutionary process of the members of the paradigmatic family Drosophilidae as a whole.

\section{ACKNOWLEDGMENTS}

People from various institutions provided HJS with valuable help in collection trips, sending material or making their labs available: Dr. Monica L. Blauth (Universidade Federal de Pelotas), Dr. Marco S. Gottschalk and Dr. Marlúcia B. Martins (Museu Paraense Emílio Goeldi), Dr. Cláudia Rohde, Dr. Ana Cristina L. Garcia (Universidade Federal de Pernambuco, Centro Acadêmico de Vitória), Dr. José Ferreira dos Santos, Dr. Tania T. Rieger, MSc. Evilis S. Monte, BSc. Luciana F. de Souto (Universidade Federal de Pernambuco, Centro de Ciências Biológicas) and Dr. Paulo R.P. Hofmann (Universidade Federal de Santa Catarina). The following people kindly identified some plant species: Dr. Lilian A. Mentz, Dr. João André Jarenkow (Universidade Federal do Rio Grande do Sul), MSc. Luiz Carlos B. Lobato, MSc. Francismeire Bonadeu da Silva and Dr. Ana Kelly Koch (Museu Paraense Emílio Goeldi). The work of Dr. David Grimaldi (American Museum of Natural History) on the Sturtevant's specimens of Drosophila bromeliae species group was very important to the present survey go further properly. This research was supported by grants and fellowships of Conselho Nacional de Desenvolvimento Científico e Tecnológico (CNPq).

\section{REFERENCES}

Acurio, A. \& Rafael, V. 2009. Diversity and geographical distribution of Drosophila (Diptera, Drosophilidae) in Ecuador. Drosophila Information Service, 92: 20-25.

Angiosperm Phylogeny Group (APG IV). 2016. An update of the Angiosperm Phylogeny Group classification for the orders and families of flowering plants: APG IV. Botanical Journal of the Linnean Society, 181: 1-20. D0I

Bächli, G.; Vilela, C.R.; Escher, S.A. \& Saura, A. 2004. The Drosophilidae (Diptera) of Fennoscandia and Denmark. Fauna Entomologica Scandinavica, 39: 1-362.

Bizzo, L.E.M.; Gottschalk, M.S.; De Toni, D.C. \& Hofmann, P.R.P. 2010. Seasonal dynamics of a drosophilid assemblage and its potential as bioindicators in open environments. Iheringia, Série Zoologia, 100: 185-191. DOI

Blanchard, E.E. 1938. Descripciones y anotaciones de Dipteros argentinos. Anales de la Sociedad Científica Argentina, 126: 345-386.

Blauth, M.L. \& Gottschalk, M.S. 2007. A novel record of Drosophilidae species in the Cerrado biome of the state of Mato Grosso, west-central Brazil. Drosophila Information Service, 90: 90-96. 
Bock, I.R. \& Parsons, P.A. 1981. Species of Australia and New Zealand. In: Ashburner, M.; Carson, H.J. \& Thompson Jr., J.N. (Eds.). The Genetics and biology of Drosophila. London, Academic Press. v. 3a, p. 291-308.

Brncic, D. 1962a. Chromosomal structure of populations of Drosophila flavopilosa studied in larvae collected in their natural breeding sites. Chromosoma, 13: 183-195.

Brncic, D. 1962b. New Chilean species of the genus Drosophila. Biologica, Santiago do Chile, 33: 3-6.

Brncic, D. 1966. Ecological and cytogenetical studies of Drosophila flavopilosa, a Neotropical species living in Cestrum flowers. Evolution, 20: 16-29.

Brncic, D. 1978. A note on the flavopilosa group of species of Drosophila in Rio Grande do Sul, Brazil, with description of two new species (Diptera, Drosophilidae). Revista Brasileira de Biologia, 38: 647-651.

Brncic, D. 1983. Ecology of flower-breeding Drosophila. In: Ashburner, M.; Carson, H.J. \& Thompson Jr., J.N. (Eds.). The Genetics and Biology of Drosophila. London, Academic Press, v. 3d, p. 333-382.

Brown, B.V. 2005. Malaise trap catches and the crisis in Neotropical dipterology. American Entomologist, 51: 180-183.

Burkart, A.; Schlindwein, C. \& Lunau, K. 2014. Assessment of pollen reward and pollen availability in Solanum stramoniifolium and Solanum paniculatum for buzz-pollinating carpenter bees. Plant Biology, 16: 503-507.

Burla, H. 1954. Study on the polymorphism in Zygothrica dispar and Z. prodispar, and description of Z. laticeps sp. nov. (Drosophilidae, Diptera). Arquivos do Museu Paranaense, 10: 231-252.

Carson, H.L. 1971. The ecology of Drosophila breeding sites. Harold L. Lyon Arboretum Lecture, 2: 1-28.

Carson, H.L. \& Okada, T. 1980. Drosophilidae associated with flowers in Papua New Guinea. I. Colocasia esculenta. Kontyu, 48: 15-29.

Carvalho-Filho, F.D.S.; Pirani, G. \& Kloss, T.G. 2018. A new species and notes on unusual natural history of Cladochaeta Coquillett, 1900 (Diptera: Drosophilidae). Zootaxa, 4410: 483-496.

Chassagnard, M.-T. \& Tsacas, L. 1992. Drosophila (Phloridosa) lutzii Sturtevant (Diptera: Drosophilidae), espécie antófila de México. Folia Entomológica Mexicana, 85: 95-105.

Chaves, N.B. \& Tidon, R. 2008. Biogeographical aspects of drosophilids (Diptera, Drosophilidae) of the Brazilian savanna. Revista Brasileira de Entomologia, 52: 340-348. D0I

Cook, R.M.; Parsons, P.A. \& Bock, I.R. 1977. Australian endemic Drosophila. II. A new Hibiscus-breeding species with its description. Australian Journal of Zoology, 25: 755-763.

Costa Lima, A. 1935. Um Drosophilideo predador de Coccideos. Chácaras e Quintaes, 52: 61-63.

De Toni, D.C.; Gottschalk, M.S.; Cordeiro, J.; Hofmann, P.R.P. \& Valente, V.L.S. 2007. Study of the Drosophilidae (Diptera) Communities on Atlantic Forest Islands of Santa Catarina State, Brazil. Neotropical Entomology, 36: 356-375. DOI

De Toni, D.C.; Hofmann, P.R.P. \& Valente, V.L.S. 2001. First record of Zaprionus indianus (Diptera, Drosophilidae) in the State of Santa Catarina, Brazil. Biotemas, 14: 71-85.

Dobzhansky, T. \& Pavan, C. 1943. Studies on Brazilian species of Drosophila. Boletim da Faculdade de Filosofia, Ciências e Letras da Universidade de São Paulo, 36: 7-72.

Dobzhansky, T. \& Pavan, C. 1950. Local and seasonal variations in relative frequencies of species of Drosophila in Brazil. Journal of Animal Ecology, 19: 1-14.

Döge, J.S.; Valente, V.L.S. \& Hofmann, P.R.P. 2008. Drosophilids (Diptera) from an Atlantic Forest area in Santa Catarina, Southern Brazil. Revista Brasileira de Entomologia, 52: 615-624. D01

Duda, 0. 1925. Die costaricanischen Drosophiliden des Ungarischen NationalMuseums zu Budapest. Annales Musei Nationalis Hungarici, 22: 149-229.
Duda, 0. 1927. Die südamerikanischen Drosophiliden (Dipteren) unter Berücksichtigung auch der anderen neotropischen sowie der nearktischen Arten. Archiv fur Naturgeschichte, 91: 1-228.

Endara, L.; Grimaldi, D.A. \& Roy, B.A. 2010. Lord of the flies: pollination on Dracula orchids. Lankesteriana, 10: 1-11. DOI

Fartyal, R.S.; Gao, J.-J.; Toda, M.J.; Hu, Y.-G.; Takenaka Takano, K.; Suwito, A.; Katoh, T.; Takigahira, T. \& Yin, J.-T. 2013. Colocasiomyia (Diptera: Drosophilidae) revised phylogenetically, with a new species group having peculiar lifecycles on monsteroid (Araceae) host plants. Systematic Entomology, 38: 763-782. DOI

Fonseca, P.M.; Loreto, E.L.S.; Gottschalk, M.S. \& Robe, L.J. 2017. Cryptic diversity and speciation in the Zygothrica genus group (Diptera, Drosophilidae): the case of $Z$. vittimaculosa Wiedemann. Insect Systematics \& Evolution, 48: 285-313.

Frota-Pessoa, 0. 1952. Flower-feeding Drosophilidae. Drosophila Information Service, 26: 101-102.

Garcia, C.F.; Hochmüller, C.J.C.;Valente, V.L.S. \& Schmitz, H.J. 2012. Drosophilid assemblages at different urbanization levels in the city of Porto Alegre, state of Rio Grande do Sul, southern Brazil. Neotropical Entomology, 41: 32-41. DOI

Giron, D.; Dubreuil, G.; Bennett, A.; Dedeine, F.; Dicke, M.; Dyer, L.A.; Erb, M.; Harris, M.0.; Huguet, E.; Kaloshian, I.; Kawakita, A.; Lopez-Vaamonde, C.; Palmer, T.M.; Petanidou, T.; Poulsen, M.; Sallé, A.; Simon, J.; Terblanche, J.S.; Thiéry, D.; Whiteman, N.K.; Woods, H.A. \& Pincebourde, S. 2018. Promises and challenges in insect-plant interactions. Entomologia Experimentalis et Applicata, 166: 319-343. DOI

Goñi, B.; Martinez, M.E.; Valente, V.L.S. \& Vilela, C.R. 1998. Preliminary data on the Drosophila species (Diptera, Drosophilidae) from Uruguay. Revista Brasileira de Entomologia, 42: 131-140.

Gottschalk, M.S.; Bizzo, L.E.M.; Döge, J.S.; Profes, M.S.; Hofmann, P.R.P. \& Valente, V.L.S. 2009. Drosophilidae (Diptera) associated to fungi: differential use of resources in anthropic and Atlantic Rain Forest areas. Iheringia, Série Zoologia, 99: 442-448. D01

Gottschalk, M.S.; De Toni, D.C.; Valente, V.L.S.\& Hofmann, P.R.P. 2007. Changes in Brazilian Drosophilidae (Diptera) Assemblages Across an Urbanization Gradient. Neotropical Entomology, 36: 848-862. D0I

Gottschalk, M.S.; Hofmann, P.R.P. \& Valente, V.L.S. 2008. Diptera, Drosophilidae: historical occurrence in Brazil. Check List, 4: 485-518. DOI

Grimaldi, D.A. 1987. Phylogenetics and taxonomy of Zygothrica (Diptera: Drosophilidae). Bulletin of the American Museum of Natural History, 186: 103-268.

Grimaldi, D.A. 2016. Revision of the Drosophila bromeliae species group (Diptera: Drosophilidae): Central American, Caribbean, and Andean Species. American Museum Novitates, 3859: 1-55. D0I

Grimaldi, D.A. \& Nguyen, T. 1999. Monograph on the spittlebug flies, genus Cladochaeta (Diptera: Drosophilidae: Cladochaetini). Bulletin of the American Museum of Natural History, 241: 1-326.

Grimaldi, D.A.; Ginsberg, P.S.; Thayer, L.; McEvey, S.; Hauser, M., Turelli, M. \& Brown, B. 2014. Strange little flies in the big city: exotic flower-breeding Drosophilidae (Diptera) in urban Los Angeles. PLOS ONE, 10: e0122575.

Hartop, E.A.; Brown, B.V. \& Disney, H.L. 2015. Opportunity in our ignorance: urban biodiversity study reveals 30 new species and one new Nearctic record for Megaselia (Diptera: Phoridae) in Los Angeles (California, USA). Zootaxa, 3941: 451-484. DOI

Hartop, E.A.; Brown, B.V. \& Disney, H.L. 2016. Flies from L.A., the sequel: a further twelve new species of Megaselia (Diptera: Phoridae) from the BioSCAN Project in Los Angeles (California, USA). Biodiversity Data Journal, e7756. DOI

Heed, W.B. 1957. Ecological and distributional notes on the Drosophilidae (Diptera) of El Salvador. The University of Texas Publications, 5721: 62-78. 
Heed, W.B.; Carson, H.L. \& Carson, M.S. 1960. A list of flowers utilized by drosophilids in the Bogota region of Colombia. Drosophila Information Service, 34: 84-85.

Hsu, T.C. 1949. The external genital apparatus of male Drosophilidae in relation to systematics. The University of Texas Publications, 4920:80-142.

Hunter, A.S. 1979. New anthophilic Drosophila of Colombia. Annals of the Entomological Society of America, 72: 372-383. D0I

Llangarí, L. \& Rafael, V. 2017. A new species of Drosophila (Diptera: Drosophilidae) from the inflorescences of Xanthosoma sagittifolium (Araceae). Revista Ecuatoriana de Medicina y Ciencias Biologicas, 38: 55-62. DOI

Magnacca, K.N.; Foote, D. \& O'Grady, P.M. 2008. A review of the endemic Hawaiian Drosophilidae and their host plants. Zootaxa, 1728: 1-58.

Malogolowkin, C. 1951. Drosophilideos colhidos na Bahia, com descrição de uma espécie nova (Diptera). Revista Brasileira de Biologia, 11: 431-434.

Malogolowkin, C. 1952. Notas sobreZygothrica dispar (Diptera, Drosophilidae). Revista Brasileira de Biologia, 12: 455-457.

May, R.M. 2010. Ecological science and tomorrow's world. Philosophical Transactions of the Royal Society, B, 365: 41-47. DOI

McEvey, S.F. \& Barker, J.S.F. 2001. Scaptodrosophila aclinata: a new Hibiscus flower-breeding species related to S. hibisci (Diptera: Drosophilidae). Records of the Australian Museum, 53: 255-262. D0I

Medeiros, H.F. \& Klaczko, L.B. 2004. How many species of Drosophila (Diptera, Drosophilidae) remain to be described in the forests of São Paulo, Brazil? Species lists of three forest remnants. Biota Neotropica, 4: 1-12. D0I

Mentz, L.A. \& Oliveira, P.L. 2004. Solanum (Solanaceae) na Região Sul do Brasil. Pesquisas. Botânica, 54: 1-327.

Montague, J.R. \& Kaneshiro, K.Y. 1982. Flower-breeding species of Hawaiian Drosophilids in an early stage of sympatry. Pacific Insects, 24: 209-213.

Pavan, C. \& Cunha, A.B. 1947. Espécies brasileiras de Drosophila. Boletim da Faculdade de Filosofia, Ciências e Letras da Universidade de São Paulo, 86: 20-64.

Pilares, G.L.V. \& Suyo, M.P. 1982. Distribution of different species of Drosophila from Peru (South America). Drosophila Information Service, 58: 122-124.

Pipkin, S.B. 1964. New flower breeding species of Drosophila. Proceedings of the Entomological Society of Washington, 66: 217-245.

Pipkin, S.B.; Rodríguez, R.L. \& León, J. 1966. Plant host specificity among flower-feeding neotropical Drosophila (Diptera: Drosophilidae). The American Naturalist, 100: 135-155. D0I

Pirani, G. \& Amorim, D.S. 2016. Going beyond the tip of the Drosophilidae iceberg: new Cladochaeta Coquillett, 1900 (Diptera: Drosophilidae) from Brazil. Zootaxa, 4139: 301-344.

Poppe, J.L.; Schmitz, H.J. \& Valente, V.L.S. 2015. The New World genus Rhinoleucophenga (Diptera: Drosophilidae): new species and notes on occurrence records. Zootaxa, 3955: 349-370.

Powell, J.R. 1997. Progress and Prospects in Evolutionary Biology. The Drosophila Model. Oxford, Oxford University Press. 562p.

Rafael, J.A.; Aguiar, A.P. \& Amorim, D.S. 2009. Knowledge of insect diversity in Brazil: challenges and advances. Neotropical Entomology, 38: 565-570. DOI

Robe, L.J.; De Ré, F.C.; Ludwig, A. \& Loreto, E.L.S. 2013. The Drosophila flavopilosa species group (Diptera, Drosophilidae): an array of exciting questions. Fly, 7: 59-69.

Roque, F. \& Tidon, R. 2008. Eight new records of drosophilids (Insecta; Diptera) in the Brazilian savanna. Drosophila Information Service, 91: 94-98.

Roque, F.; Figueiredo, R. \& Tidon, R. 2006. Nine new records of drosophilids in the Brazilian savanna. Drosophila Information Service, 89: 14-17.

Sakai, S. 2002. Aristolochia spp. (Aristolochiaceae) pollinated by flies breeding on decomposing flowers in Panama. American Journal of Botany, 89: 527-534. DOI
Sánchez-Bayo, F.\&Wyckhuys, K.A.G. 2019. Worldwide decline of entomofauna: a review of its drivers. Biological Conservation, 232: 8-27. DOI

Santa-Brígida, R.; Schmitz, H.J. \& Martins, M.B. 2017. Drosophilidae (Insecta, Diptera) in the state of Pará (Brazil). Biota Neotropica, 1: e20160179. DO

Santos, R.C.O. \& Vilela, C.R. 2005. Breeding sites of Neotropical Drosophilidae (Diptera). IV. Living and fallen flowers of Sessea brasiliensis and Cestrum spp. (Solanaceae). Revista Brasileira de Entomologia, 49: 544-551. D01

Schmitz, H.J. \& Hofmann, P.R.P. 2005. First record of subgenus Phloridosa of Drosophila in southern Brazil, with notes on breeding sites. Drosophila Information Service, 88: 97-101.

Schmitz, H.J.; Gottschalk, M.S. \& Valente, V.L.S. 2009. Rhinoleucophenga joaquina sp. nov. (Diptera: Drosophilidae) from the Neotropical Region. Neotropical Entomology, 38: 786-790. DOI

Schmitz, H.J.; Valente, V.L.S. \& Hofmann, P.R.P. 2007. Taxonomic survey of Drosophilidae (Diptera) from mangrove forests of Santa Catarina Island, southern Brazil. Neotropical Entomology, 36:53-64. DO

Silva, A.A.R. \& Martins, M.B. 2004. A new anthophilic species of Drosophila Fallén belonging to the bromeliae group of species (Diptera, Drosophilidae). Revista Brasileira de Zoologia, 21: 435-437. D0I

Silva, N.M.; Fantinel, C.C.; Valente, V.L.S. \& Valiati, V.H. 2005. Ecology of colonizing populations of the fig fly Zaprionus indianus (Diptera, Drosophilidae) in Porto Alegre, southern Brazil. Iheringia, Série Zoologia 95: 233-240. DOI

Souza, V.C. \& Lorenzi, H. 2005. Botânica Sistemática - guia ilustrado para identificação das famílias de angiospermas da flora brasileira, baseado em APG II. Nova Odessa, Plantarum. 639p.

Starmer, W.T. \& Bowles, J.M. 1994. The spatial distribution of endemic and introduced flower-breeding species of Drosophila (Diptera: Drosophilidae) during their early history of encounter on the islands of Hawaii. Pan-Pacific Entomologist, 70: 230-239.

Sturtevant, A.H. 1916. Notes on North American Drosophilidae with descriptions of twenty-three new species. Annals of the Entomological Society of America, 9: 323-343. DOI

Sturtevant, A.H. 1921. The North American species of Drosophila. Carnegie Institute of Washington Publication, 301: 1-150. DOI

Sturtevant, A.H. 1942. The classification of the genus Drosophila, with descriptions of nine new species. The University of Texas Publication, 4213: 5-51.

Sultana, F.; Hu, Y.G.; Toda, M.J.;Takenaka, K. \& Yafuso, M. 2006. Phylogeny and classification of Colocasiomyia (Diptera, Drosophilidae), and its evolution of pollination mutualism with aroid plants. Systematic Entomology, 31: 684-702. DOI

Sultana, F.; Kimura, M.T. \& Toda, M.J. 1999. Anthophilic Drosophila of the elegans species-subgroup from Indonesia, with description of a new species (Diptera: Drosophilidae). Entomological Science, 2: 121-126.

Tidon, R. 2006. Relationships between drosophilids (Diptera, Drosophilidae) and the environment in two contrasting tropical vegetations. Biological Journal of the Linnean Society, 87: 233-247.

Tidon, R.; Gottschalk, M.S.; Schmitz, H.J. \& Martins, M.B. 2019. Drosophilidae. In: Catálogo Taxonômico da Fauna do Brasil. PNUD. Available in: D0I. Access in: 19/06/2019.

Tsacas, L. \& Chassagnard, M.-T. 1992. Les relations Araceae-Drosophilidae. Drosophila aracea une espèce anthophile associée à l'Aracée Xanthosoma robustum au Mexique (Diptera: Drosophilidae). Annales de la Societé Entomologique de France, 28: 421-439.

Tsacas, L.; Chassagnard, M.-T. \& David, J.R. 1988. Un nouveau groupe d'espèces afrotropicales anthophiles dans le sous-genre Scaptodrosophila du genre Drosophila (Diptera, Drosophilidae). Annales de la Societé Entomologique de France, 24: 181-202. 
Val, F.C. 1982. The male genitalia of some Neotropical Drosophila: notes and illustrations. Papéis Avulsos de Zoologia, 34: 309-347.

Valadão, H.; Proença, C.E.B.; Kuhlmann, M.P.; Harris, S.A. \& Tidon, R. 2019. Fruit-breeding drosophilids (Diptera) in the Neotropics: playing the field and specializing in generalism? Ecological Entomology, (2019). D0I

Valente, V.L.S.; Ruszczyk, A.; Dos Santos, R.A.; Bonorino, C.B.C.; Brum, B.E.P.; Regner, L. \& Morales, N.B. 1989. Genetic and ecological studies on urban and marginal populations of Drosophila in the south of Brazil. Evolución Biologica, 3: 19-35.

Valer, F.B.; Bernardi, E.; Mendes, M.F.; Blauth, M.L. \& Gottschalk, M.S. 2016. Diversity and associations between Drosophilidae (Diptera) species and Basidiomycetes in a Neotropical forest. Anais da Academia Brasileira de Ciências, 88: 705-718. DOI

Vaz, S.C.; Vilela, C.R. \& Carvalho, A.B. 2018. Two new species of Drosophila (Diptera, Drosophilidae) associated with inflorescences of Goeppertia monophylla (Marantaceae) in the city of São Paulo, state of São Paulo, Brazil. Revista Brasileira de Entomologia, 62: 159-168. D0I

Vaz, S.C.; Vilela, C.R.; Krsticevic, F.J. \& Carvalho, A.B. 2014. Developmental sites of Neotropical Drosophilidae (Diptera): V. Inflorescences of Calathea cylindrica and Calathea monophylla (Zingiberales: Marantaceae). Annals of the Entomological Society of America, 107: 607-620. D01
Vidal, M.C.; Sendoya, S.F.; Yamaguchi, L.F.; Kato, M.J.; Oliveira, R.S. \& Oliveira, P.S. 2018. Natural history of a sit-and-wait dipteran predator that uses extrafloral nectar as prey attractant. Environmental Entomology, 47: 1165-1172.

Vilela, C.R. 1984. Notes on the holotypes of four Neotropical species of the genus Drosophila (Diptera, Drosophilidae) described by A.H. Sturtevant. Revista Brasileira de Entomologia, 28: 245-256.

Vilela, C.R. 1986. The type-series of Drosophila denieri Blanchard (Diptera, Drosophilidae). Revista Brasileira de Entomologia, 30: 223-226.

Vilela, C.R. \& Mori, L. 1999. The genus Drosophila (Diptera, Drosophilidae) in the Serra do Cipó: further notes. Revista Brasileira de Entomologia, 43: 319-128.

Vilela, C.R. \& Prieto, D. 2018. A new Costa Rican species of Drosophila visiting inflorescences of the hemi-epiphytic climber Monstera lentii (Araceae). Revista Brasileira de Entomologia, 62: 225-231. D01

Yafuso, M.; Toda, M.J. \& Sembel, D.T. 2008. Arengomyia, new genus for the Colocasiomyia arenga species group (Diptera: Drosophilidae), with description of a new species. Entomological Science, 11: 391-400.

Yassin, A. 2013. Phylogenetic classification of the Drosophilidae Rondani (Diptera): the role of morphology in the postgenomic era. Systematic Entomology, 38: 349-364. 


\section{SUPPLEMENTARY MATERIAL}

Appendix S1. List of plant species with no emergence of drosophilid specimens in the present survey.

\begin{tabular}{|c|c|}
\hline Family & Species \\
\hline \multirow[t]{4}{*}{ Acanthaceae } & Justicia floribunda \\
\hline & Sanchezia oblonga \\
\hline & Odontonema strictum \\
\hline & sp.1 \\
\hline Amaryllidaceae & Agapanthus africanus \\
\hline \multirow[t]{2}{*}{ Asteraceae } & Mikania cordifolia \\
\hline & Senecio brasiliensis \\
\hline \multirow[t]{4}{*}{ Apocynaceae } & Allamanda blanchetii \\
\hline & Nerium oleander \\
\hline & Tabernaemontana catharinensis \\
\hline & Thevetia peruviana \\
\hline Araceae & sp.1 \\
\hline Balsaminaceae & Impatiens walleriana \\
\hline Begoniaceae & Begonia coccinea \\
\hline \multirow[t]{2}{*}{ Bignoniaceae } & Adenocalymma schomburgkii \\
\hline & Podranea ricasoliana \\
\hline Cactaceae & Opuntia cochenillifera \\
\hline \multirow[t]{2}{*}{ Cannaceae } & Canna indica \\
\hline & Canna paniculata \\
\hline Cleomaceae & Tarenaya hassleriana \\
\hline Convolvulaceae & Ipomoea imperati \\
\hline Commelinaceae & Tradescantia sp. \\
\hline Cucurbitaceae & Momordica charantia \\
\hline \multirow[t]{2}{*}{ Ericaceae } & Gaylussacia brasiliensis \\
\hline & Rhododendron simsii \\
\hline Escalloniaceae & Escallonia bifida \\
\hline Euphorbiaceae & Euphorbia pulcherrima \\
\hline \multirow[t]{6}{*}{ Fabaceae } & Bauhinia forficata \\
\hline & Delonix regia \\
\hline & Lupinus sp. \\
\hline & Macroptilium lathyroides \\
\hline & Peltophorum dubium \\
\hline & Schizolobium parahyba \\
\hline Geraniaceae & Pelargonium $\mathrm{x}$ hortorum \\
\hline Heliconiaceae & Heliconia farinosa \\
\hline
\end{tabular}

\begin{tabular}{|c|c|}
\hline Family & Species \\
\hline Iridaceae & Gladiolus x hortulanum \\
\hline Lamiaceae & Salvia coccinea \\
\hline \multirow[t]{2}{*}{ Liliaceae } & Lilium regale \\
\hline & Lilium sp.1 \\
\hline \multirow[t]{2}{*}{ Lythraceae } & Lagerstroemia indica \\
\hline & Punica granatum \\
\hline Magnoliaceae & Magnolia liliflora \\
\hline \multirow[t]{4}{*}{ Malvaceae } & Abelmoschus esculentus \\
\hline & Brachychiton populneus \\
\hline & Hibiscus schizopetalum \\
\hline & Luehea divaricata \\
\hline Melastomataceae & Tibouchina urvilleana \\
\hline Musaceae & Musa ornata \\
\hline Nymphaeaceae & Nymphaea ampla \\
\hline Oleaceae & Jasminum mesnyi \\
\hline Onagraceae & Ludwigia sp. \\
\hline \multirow[t]{2}{*}{ Orchidaceae } & Epidendrum fulgens \\
\hline & sp.1 \\
\hline \multirow[t]{2}{*}{ Oxalidaceae } & Oxalis corniculata \\
\hline & Oxalis latifolia \\
\hline Piperaceae & Pipersp. \\
\hline \multirow[t]{2}{*}{ Plantaginaceae } & Russelia equisetiformis \\
\hline & sp.1 \\
\hline Proteaceae & Grevillea banksii \\
\hline Rosaceae & Rosa spinosissima \\
\hline \multirow[t]{5}{*}{ Solanaceae } & Datura stramonium \\
\hline & Petunia integrifolia \\
\hline & Petunia sp. \\
\hline & Solanum pycnanthemum \\
\hline & Streptosolen jamesonii \\
\hline Urticaceae & Cecropia pachystachya \\
\hline \multirow[t]{2}{*}{ Verbenaceae } & Lantana camara \\
\hline & Petrea subserrata \\
\hline Zingiberaceae & Renealmia cf. petasites \\
\hline
\end{tabular}

